\title{
The Role of Water-Food-Energy Nexus in Achieving Sustainable Agriculture
}

\author{
Jacques Ganoulis* \\ UNESCO Chair for Water, Aristotle University of Thessaloniki, Greece \\ *Corresponding author: Jacques Ganoulis, UNESCO Chair for Water, Aristotle University of Thessaloniki, Greece
}

\section{Introduction}

The UN Rio declaration [1] has initiated in 1992 many international initiatives, research activities, academic programs, and policy frameworks, aiming to define and implement the concept of "sustainable development". This term was first introduced in the report to the UN, established in 1987 by the World Commission on Environment and Development, chaired by Mrs. Brundland, Norway's Prime Minister, commonly known as the Brundland Report [2]. Although the term "sustainable development" is until now not completely clear, it was understood as the development that combines socio-economic growth with environmental protection and social equity.

The majority of the UN Member States have agreed in 2000 to adopt eight "Millennium Development Goals" (MDGs) [3], that all have measurable targets for monitoring the progress made for achieving sustainability. Every target has a number of more particular indicators, some of them been related to water, energy, and food. For example, the seventh MDG on environmental sustainability has among others, the target of achieving safe drinking water and sanitation. The same MDG 7 refers to energyrelated indicators, such as the amount of energy used per GDP, the population proportion using solid fuels and the $\mathrm{CO} 2$ emissions per capita. Also, different concerns on food production were formulated as a first priority in the MDG 1: Eradicate extreme poverty and hunger.

The UN General Assembly has adopted in 2015 a working plan named the "2030 Agenda for Sustainable Development" [4]. This global planning contains 17 Sustainable Development Goals (SDGs), many of which are related to water, energy and food. More precisely, the Goal 6: ensure availability and sustainable management of water and sanitation for all, the Goal 13: take urgent action to combat climate change and its impacts and the Goal 2: end hunger, achieve food security and improved nutrition and promote sustainable agriculture. According to UN SecretaryGeneral António Guterres, climate change is the defining issue of our time. Due to high atmospheric concentrations of greenhouse gases emitted from different fossil energy sources, such as industries, cars and airplanes, climate change is becoming the most important challenge humanity faces today. Rise of the atmospheric temperature induces changes in precipitation patterns and also increase of hydrological extremes, such as floods and droughts. This means that again water and energy sustainability are the main keys to adaptation and mitigation under climate change. Concerning the goal of water security, the concept of Integrated Water Resources Management (IWRM), was introduced in 2000 by the Global Water Partnership, an NGO based in Stockholm, as the most appropriate framework for water security [5]. The main idea is that water management cannot be considered in isolation from other natural resources, such as the soil, the forests, and the water-related ecosystems and that a holistic and interdisciplinary approach taking into account economic and social considerations is more appropriate. In fact, the elements to integrate in this approach are not well defined and the implementation of IWRM in practice has revealed many difficulties. Based on similar concepts, the IWRM methodology has been adopted in 2000 by the European Union, as a policy framework, known as the EU Water Framework Directive (EU-WFD) [6]. The adoption of the EU-WFD by the European Member States is compulsory and failure to integrate the water directive into the national legal framework may induce fines from the European Court.

\section{The Water-Energy-Food Nexus (WEF)}

Water, energy, and food are three important resources inextricably linked in terms of mutual relationships and interactions. For example, increasing the use of water in agricultural irrigation generates supplementary energy consumption for transferring or pumping water. Plants producing food need water but from the other side, agricultural activities may increase groundwater pollution from pesticides and fertilizers. Water is also needed for energy production and in the opposite sense, the use of energy may increase the amount of wastewater and water pollution. 
The Latin name "nexus" means a knot or a link and it has been used during the last few years to express the strong relationship between water, energy and food. In fact, the water-energy-food (WEF) nexus was mentioned by the World Economic Forum in 2011, as the most important issue for sustainable development [7]. In the real world, there are three main issues related to this "nexus":

a. The word "nexus" indicates our inability to understand and define the integrated process linking water, energy, and food

b. From the scientific point of view, "nexus" means that we don't know how to assess, represent and predict the consequences of linking water, energy, and food

c. In relation to governance, "nexus" represents our inability to build up institutions, able to manage in coordinated approach water, energy and food.

According to FAO [8], the three elements that are included in the nexus are not sufficient to guarantee sustainability; it is necessary next to the water, energy, and food to add some other equally important issues, such as the environment, the land use and the climate change. Also, the challenge to secure by the nexus local livelihoods and the human rights to water and food was pointed out [9]. If we enlarge the meaning of the nexus by considering the SDGs achievement [10], then the differentiation between the nexus and the IWRM framework becomes narrow and not easily understood.

\section{The Unique Role of Water}

Specialists in one particular discipline among the three that are included in the nexus usually claim that their domain of expertise is more important and that their discipline dominates the other two. In every real problem involving the nexus, there are winners and losers between those three. For example, huge agricultural food production in Greece and other parts of the world has been obtained by the overuse of groundwater resources for irrigation water and intensive consumption of energy. In some areas, groundwater levels were greatly decreased and groundwater aquifers have been depleted. If water security is at risk and water availability is critical, no other resource of the nexus, i.e. energy or food can survive. In conclusion, water is the "sine qua non" (without which nothing) element that is the origin of life and the necessary support for the existence of terrestrial and aquatic ecosystems.

\section{Towards A Hydro-Centric Nexus for Sustainable Agriculture}

The "nexus" problem is very complex and almost unsolvable even if it is formulated in mathematical terms. It is a multi-objective, multidimensional and non-stationary problem consisting of the following three objectives, namely water, energy, and food. These three objectives are linked together and everyone is a function of many variables, such as space, the time, the cost, the environmental impact, the kind of energy resource (fossil, nuclear, renewable) and the hydrological conditions. For any particular case study, the aim is to maximize food (agricultural production) and minimize the costs, and the amount of water and energy. This is a multi-objective optimization problem that mathematically hasn't a unique optimum solution. Mathematically, only one objective can be optimized, e.g. agricultural production corresponding to the minimum cost. By considering all three variables together, the risk consists of overusing the available water resources and energy in order to maximize food. This is obviously non-sustainable agriculture. Apart from the unique property of water as being a source of life, water is not only a "renewable" but also a "recyclable" resource, through the process of precipitation and evaporation in the hydrological water cycle. Water resources can also be naturally stored in the form of groundwater resources, in contrast to solar power and wind energy that are good renewable resources but without natural storage capabilities.

As a conclusion, the hydro-centric nexus paradigm for sustainable agriculture we are proposing, consists of evaluating first the long-term renewable and stored water resources potential and then, examine only nexus alternative solutions that respect the water security.

\section{References}

1. UN Resolution (1992) The Rio declaration on environment and development.

2. Brundtland GH (1987) Our Common Future. Report of the World Commission on Environment and Development.

3. Millennium Development Goals (MDGs) (2000) Integrated Water Resources Management.

4. UN Resolution (2015) Transforming our world: the 2030 Agenda for Sustainable Development.

5. Global Water Partnership (GWP) (2000) Integrated Water Resources Management. Technical Advisory Committee (TAC) N04.

6. European Commission (2016) Water information system for Europe. Introduction to the new EU Water Framework Directive.

7. Simpson GB, Jewitt GPW (2019) The Development of the Water-EnergyFood Nexus as a Framework for Achieving Resource Security: A Review Front Environ Sci 7: 8.

8. FAO (2014) The Water-Energy-Food Nexus A New Approach in Support of Food Security and Sustainable Agriculture.

9. Hoff H (2011) "Understanding the Nexus," in Background Paper for the Bonn 2011 Conference: The Water, Energy and Food Security Nexus. Stockholm: Stockholm Environment Institute.

10. Salam PA, Pandey VP, Shrestha S, Anal AK (2017) The need for the nexus approach. In Water-Energy-Food Nexus: Principles and Practices, (eds.). P Abdul Salam, S Shrestha, V Prasad Pandey. 
cC (D) This work is licensed under Creative Commons Attribution 4.0 License To Submit Your Article Click Here: Submit Article

DOI: $10.32474 /$ CIACR.2020.08.000290

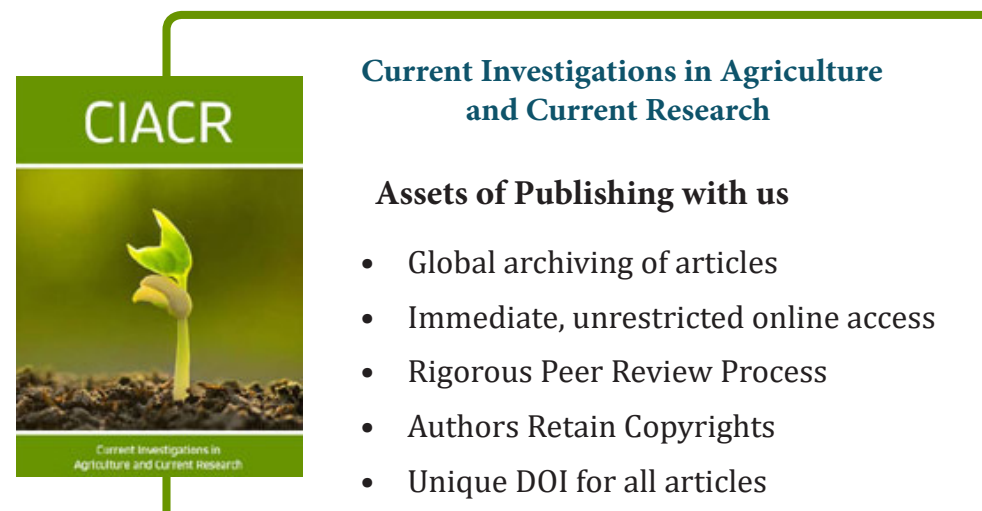

